\title{
Current status of ticks and tick-host relationship in domestic and wild animals from Pantanal wetlands in the state of Mato Grosso do Sul, Brazil
}

\author{
Paulo Henrique Duarte Cançado', João Luiz Horácio Faccini², Guilherme de Miranda Mourão \\ Eliane Mattos Piranda ${ }^{4}$, Valéria Castilho Onofrio ${ }^{5} \&$ Darci Moraes Barros-Battestio
}

\footnotetext{
1. Empresa Brasileira de Pesquisa Agropecuária, Embrapa Gado de Corte. Av. Rádio Maia, 830, Caixa Postal 154, $79106-550$ Campo Grande, MS, Brasil. (paulo.cancado@embrapa.br)

2. Universidade Federal Rural do Rio de Janeiro, Instituto de Veterinária, Departamento de Parasitologia Animal. BR 465, Km 7, 23890-000 Seropédica, RJ, Brasil.

3. Empresa Brasileira de Pesquisa Agropecuária. Centro de Pesquisa Agropecuária do Pantanal. Rua 21 de Setembro, 1880, Caixa Postal 10, 79320-900 Corumbá, MS, Brasil.

4. Universidade Federal de Mato Grosso do Sul, Centro de Ciências Biológicas e da Saúde. Cidade Universitária s/n²,79070-900 Campo Grande, MS, Brasil.

5. Universidade de Santo Amaro. Rua Professor Enéas de Siqueira Neto, 340, Cidade Dutra, 04829-300 São Paulo, SP, Brasil.

6. Instituto Butantan, Secretaria da Saúde, Laboratório de Parasitologia. Av. Vital Brasil, 1500, Butantã 05503-900 São Paulo, SP, Brasil.
}

Received 12 December 2016

Accepted 6 February 2017

DOI: $10.1590 / 1678-4766 e 2017110$

\begin{abstract}
This is a commented list of tick's species collected on various wild and domestic animals, including the reports on scientific literature for the studied region. Most of animals were small or medium mammals. Carnivores were the main taxa group examined. Although, the pampas deer (Ozotocerus bezoarticus) and giant anteater (Mymercophaga tridactyla) also has a good representation on study. Among domestic animals, dogs, horses and cattle were examined. Summing up, 18 tick species were listed for the region. Sixteen were hard ticks (Ixodidae) and two soft ticks (Argasidae). Amblyomma sculptum was the most common and abundant hard tick. Ornithodoros rostratus (Argasidae) was very abundant, being the more important Argasidae tick on the study region. The following species were colleted or reported on scientific literature: Argas miniatus Koch, 1844; Ornithodoros rostratus Aragão, 1911; Dermacentor nitens Newmann, 1897; Rhipicephalus (Boophilus) microplus Canestrini, 1887; Amblyomma tigrinum Koch, 1844; A. dissimile Koch, 1844; A. ovale Koch, 1844; A. pauvum Aragão, 1908; A. sculptum Berlese, 1888; A. calcaratum Neumann, $1899 ;$ A. coelebs Neumann, 1899; A. dubittatum Newmann, 1899; A. scalpturatum Newmann, 1906; A. naponense Packard, 1869; A. nodosum Newmann, 1899; A. pseudoconcolor Aragão, 1908; A. rotundatum Koch, 1844; A. triste Koch, 1844.
\end{abstract}

KEYWORDS. Nhecolândia, Argasidae, Ixodidae, Pantanal, Biota-MS Program.

RESUMO. Estado atual dos carrapatos em relação a seus animais-hospedeiros domésticos e selvagens do Pantanal no Estado do Mato Grosso do Sul, Brasil. Este artigo consiste de uma lista comentada das espécies de carrapatos coletadas em diversas espécies de animais selvagens e domésticos incluindo aquelas espécies já reportadas na região. Os animais capturados são em sua maioria mamíferos de pequeno e médio porte. Os carnívoros foi o grupo com maior número de observações. Entretanto, o veado campeiro (Ozotocerus bezoarticus) e o tamanduá bandeira (Mymercophaga tridactyla) também tiveram um número significativamente de amostras. Dentre os animais domésticos, cães, equinos e bovinos foram examinados. No total foram listadas 18 espécies de carrapatos para a região. Dezesseis delas são carrapatos duros (Ixodidae) e duas, carrapatos moles (Argasidae). Dentre os Ixodidae, Amblyomma sculptum foi a espécie mais encontrada, sendo considerada a mais abundante na região. Ornithodoros rostratus (Argasidae) mostrou-se frequente e abundante, sendo o principal representante da família. Somando as coletas com os resultados de literatura, as seguintes espécies foram catalogadas para a região: Argas miniatus Koch, 1844; Ornithodoros rostratus Aragão, 1911; Dermacentor nitens Newmann, 1897 ; Rhipicephalus (Boophilus) microplus Canestrini, 1887; A. tigrinum Koch, 1844; A. dissimile Koch, 1844; A. ovale Koch, 1844; A. parvum Aragão, 1908; A. sculptum Berlese, 1888; A. calcaratum Neumann, 1899; A. coelebs Neumann, 1899; A. dubittatum Newmann, 1899; A. scalpturatum Newmann, 1906; A. naponense Packard, 1869; A. nodosum Newmann, 1899; A. pseudoconcolor Aragão, 1908; A. rotundatum Koch, $1844 ;$ A. triste Koch, 1844.

PALAVRAS-CHAVE. Nhecolândia; Argasidae; Ixodidae; Pantanal; Programa Biota-MS

The Brazilian Pantanal wetland is the largest seasonal floodplain in the world and the major economic activity is cattle production. Brazil is the largest exporter of bovine beef in the world and the Pantanal region plays a key role in beef cattle production. Moreover, Pantanal is considered a hotspot for conservation by UNESCO. The Pantanal is undergoing major transformation due to changes in cattle management and introduction of alien species leading to more productive pastures and consequently increasing bovine density. Hostparasite relationship in natural habitats has resulted from a long period of co-evolution and, in most cases, interactions are complex and in equilibrium, such as among ticks, hosts and tick-borne-diseases.

Environmental changes and habitat fragmentation are being pointed out as the primary cause for the loss of biodiversity (MCCALLUM \& DoBSON, 2002). Along with the 
high-speed development of cattle production and ecotourism, these circumstances have made the Pantanal into a hotspot for emerging and re-emerging parasitic diseases. CANÇADO et al. $(2008,2009)$ showed different aspects of the impact of cattle production on tick populations in the field and some implication for wildlife in the Pantanal. Few studies have been conducted in the Pantanal concerning ticks and tick-borne diseases. Therefore, tick fauna and its potential to transmit or maintain disease are almost unknown. Nevertheless, the following papers show a huge diversity of ticks (MACHADO et al., 1985; Ito et al., 1998; PEREIRA et al., 2000; MARTINS et al., 2004; LABRUNA et al., 2005; CANÇADO et al., 2008) and the introduced Rhipicephalus (Boophilus) microplus (Canestrini, 1887) has been found on wild animals (ITO et al., 1998; PEREIRA et al., 2000; CANÇADO et al., 2009), although most of these papers were based on occasionally collected samples and did not allow adequate analysis of the dynamics of the environment and tick-host relationships.

This paper aims to gather information on tick-host relationships in the Pantanal and provides an updated list of species based on collected ticks and on scientific literature. Comments concerning each tick species based on field observations have also been included.

\section{MATERIAL AND METHODS}

Studied area. Research was carried out in southern Pantanal (Nhecolândia's sub-region - 19 $08^{\prime} 28^{\prime}$ 'S and $\left.56^{\circ} 49^{\prime} 23^{\prime \prime} \mathrm{W}\right)$. The field laboratory and base camp was located at Nhumirim ranch at EMBRAPA Pantanal. The region is characterized by sandy soil with a mosaic vegetation of semideciduous forest, dispersed shrub vegetation and seasonally flooded fields (RoDELA et al., 2008). The region has two seasons, a wet season (October to March - 70\% rain) and a dry season (April to September). The annual average temperature is $25.5^{\circ} \mathrm{C}$ and relative humidity ( $\left.\mathrm{RH}\right)$ is approximately $75 \%$ throughout the year. A detailed description of this region can be found in Soriano et al. (1997).

Capturing and handling procedures. The following domestic animals were examined: bovines, dogs, horses and chickens. Authorization for handling domestic animals was granted by owners. Procedures for wild animals are presented below. After proper handling, animals were ear-tagged. All procedures were authorized by the Brazilian Institute of the Environment (IBAMA) under licenses 026/2005, 032/2005 183/2005-003/2006. Ethical guidelines for animal research from Colégio Brasileiro de Experimentação Animal (COBEA) were followed as well as the Guidelines for Capture, Handling and Care of Mammals approved by the American Society of Mammalogists (Animal Care and Use Committee 1998).

Ticks on wild animals. In general, all ticks encountered on animals following anesthesia were collected. Ticks were only partially collected from the giant-anteater due to the enormous number of ticks encountered. Nymphs and adult ticks were captured by hand only and larvae were collected by hand as well as using a soft toothbrush. A small number of larvae were destroyed by this kind of collection, making them impossible to identify.

Feral pigs. Feral pigs (Sus scrofa Linnaeus, 1758) were captured by fence traps or by cowboys using ropes to catch them with. All captured pigs were tranquilized (tiletamine hydrochloride and zolazepan hydrochloride, Zoletil $^{\circledR}$, Virbac) prior to examination for tick collection.

Carnivores. Captured carnivores included the brownnosed coati (also known as the Brazilian aardvark, Nasua nasua Linnaeus, 1766), the crab-eating fox (Cerdocyon thous Linnaeus, 1766), the ocelot (or dwarf leopard, Leopardus pardalis Linnaeus, 1758) and the crab-eating raccoon (known as mão pelada in portuguese, Procyon cancrivorus Cuvier, 1798 ) were captured. With exception to P. cancrivorus, a live animal wire box trap ( $1 \mathrm{~m}$ x $0.40 \mathrm{~m}$ x $0.50 \mathrm{~m}-$ Zootec $\left.^{\circledR}\right)$ baited with bacon, fruits or fish was used. Individuals were anesthetized with an intramuscular injection of Zoletil $^{\circledR} 50$ (Virbac ${ }^{\circledR}$; tiletamine hydrochloride and zolazepan hydrochloride). The dose of anesthetics was determined by RocHA (2006). Other host species captured by these traps were the agouti (Dasiprocta azarae Lichtenstein, 1823), the six-banded armadillo (Euphractus sexcintus Linnaeus, 1758) and the collared-anteater (Tamandua tetradactyla Linnaeus, 1758).

Procyon cancrivorus were only captured at night using high-power lights and nets. The process of capture included searching for animals near lakes by pointing lights and searching for their eyes. When an animal was found, two people would shine the lights in its eyes to block its view while a third person would use the net to catch it. Apart from its capture, anesthesia and other procedures were the same as those for other carnivores.

Giant-anteater (Mymercophaga tridactyla Linnaeus, 1758). As this species has restricted variety but abundant food and is easy to locate, it was captured by nets. To locate these animals a motorized vehicle was used and when found it was approached by slowly walking followed by running. The dose of anesthetics was calculated according to manufacturer's recommendations for this species.

Collared anteater (Tamandua tetradactyla). These animals were only captured occasionally when they were located in "easy to catch" situations or accidentally captured by the live animal wire box trap. Handling procedures included the use of leather gloves for researcher's protection. Other procedures followed the same protocol as those used for the giant-anteater.

Pampas deer (Ozotoceros bezoarticus Linnaeus, 1758). Procedures used for the pampas deer are described in Piovezan et al. (2006) and CANÇAdo et al. (2008).

Small mammals. Small mammals were captured by using two different kinds of traps: Shermann ${ }^{\odot}$ and Tomahawk $^{\odot}$. We prepared a mixture of bacon, nuts and vegetable oil to use as bait. These traps were set up at different areas of Nhumirim ranch, some directly on the ground and others in trees for the capture of both ground and arboreal species. For handling procedures, cotton bags and gloves were used and no anesthetic procedures were necessary for 
most of these mammals. Research focused on two species of rodents, Thrichomys spp. e Clyomys spp.

Snakes (Bothrops matogrossensis Amaral, 1925). On some occasions, especially when snakes were found near schools or houses, locals would kill them for their own protection. In these cases, snakes were examined for ticks.

Observations on humans. During all field trips we collected ticks attached to either the researchers or locals.

Tick storage. Engorged ticks were kept alive in a high relative humidity chamber $(>70 \%)$ to allow females to lay eggs and immature ticks to molt. These chambers were made of small plastic boxes with a humid cotton ball inside and holes made with needles to allow air exchange. All others ticks were maintained in glass flasks with $70 \%$ ethyl alcohol and labeled with the date and host number.

Tick identification. All ticks were identified by comparing morphological aspects using the most recent identification keys for Neotropical ticks (Guimarães et al., 2001; BARRos-BATtesti et al., 2006). Immature stages were identified for genus only.

Some representative ticks for each host species were sent to the Acarology Collection of the Butantan Institute, São Paulo, SP, Brazil (IBSP).

\section{RESULTS}

Argas miniatus Koch, 1844. This argasid tick was collected in two different opportunities in the same chicken shed on a Ranch (1908'28'S, 56 49'3' W). This was done by chance when the owner called for veterinary assistance to investigate chicken deaths. Ticks were collected and treatment was recommended. After a few weeks, egg production was shown to increase while deaths ceased. Eight months later a lighter infestation occurred in the same chicken shed. One probable source for the reinfestation was wild birds.

The collected ticks were sent to the Laboratory of Ixodology at UFRRJ where they were allowed to feed on chickens. Tick hemolymph and chicken blood were examined under a microscope and no pathogens were observed. The importance of this tick species is not clearly known, however, losses in productivity due to blood feeding, transmission of pathogens such as Borrelia anserine and paralysis induced by larvae in young birds have been reported (SANTOS et al., 2010). Because of the great abundance and diversity of wild birds in close contact with domestic animals in the Pantanal region, further research on the host-relationship of this tick is recommended.

Ornithodoros rostratus Aragão, 1911. This tick species was first identified on feral pigs. On this occasion, four nymphs were collected. In the Laboratory of Ixodology (UFRRJ), these nymphs were placed to feed on domestic pigs to initiate a colony. After colony establishment, ticks were allowed to feed on rabbits under laboratory conditions.

In the Pantanal, we found $O$. rostratus feeding on dogs which are often found resting near residences on sand soils protected from sunlight by trees. Associated ecchymosis-like lesions were seen on the dogs' belly. When local residents where asked about the ticks, they complained about fever, red ecchymosis-like spots, lymph node swelling and itch following a tick bite.

One hundred fourteen specimens of $O$. rostratus were collected by $\mathrm{CO}_{2}$ tick trap in a calf pen during a two hour trap effort (CANÇADO et al., 2008). The floor of the pen consisted of a mixture of soft sand soil, leaves and dry bovine feces. Bovines were maintained in the pen for two hours in the morning before milking. During milking, dogs owned by locals entered the pen.

Partial information on the life cycle can be found in (GUGLIELMONE \& HADANI, 1980). In some countries, species of Ornithodoros have a major role in disease transmission, such as borreliosis and typhus (HoogstraAl, 1985). Since the 1930s, this tick is known as vector of important tick-borne diseases, such as Brazilian Spotted Fever in humans (LemosMonteiro et al., 1932; Labruna, 2009). Nevertheless, massive experimental research is necessary to clarify the role of $O$. rostratus in the epidemiology of tick-borne diseases of cattle, humans and wildlife.

Dermacentor nitens (Neumann, 1897). This species is known to widely affect horses. It can be found inside ears, at the tail base, nostrils and mane (Borges \& Leite, 1993; Guglielmone et al., 2006). In the Pantanal region, horses have enormous significance to cattle management efforts and consequently to the local economy. Dermacentor nitens is vector of the protozoan Babesia caballi. A total of 51 ticks were collected on 12 out of 21 horses (Tab. I). Three of these horses have lost one or both ears after massive tick infestations.

Rhipicephalus (Boophilus) microplus (Canestrini, 1887). We found $R$. microplus in two examined species of ruminants; cattle and pampas deer (O. bezoarticus). PereIRA et al. (2000) and LABRUNA et al. (2005a) found this tick on wild animals in the Pantanal, and the deer was the most common wild host (Tab. II). One hundred seventy four bovines, of which 20 Bos indicus Linnaeus, 1758 (nelore) and 124 Bos taurus Linnaeus, 1758 (adapted breed, tucura) were searched. The prevalence of $43 \%$ was considered high and the rate of ticks per bovine was 0.58 ticks/animal (Tab. I). On the other hand the pampas deer have $76 \%$ prevalence and the rate of ticks was 9.7 ticks/animal (CANÇADO et al., 2009).

The pampas deer's antler growth occurs during the beginning of the dry season and requires a great energy investment (Tomas, 1995). In this period, the deer are in poor health conditions in which lower resistance possibly accounts for the apparent increase in tick population (CANÇADO et al., 2009). Ticks have been found around the base of growing antlers in an area of high blood flow. The biological importance of this tick behavior is unknown and more researches are necessary to clarify this issue.

In addition, the pampas deer (O. bezoarticus) probably play an important role in the epidemiology of Anaplasma spp. in the Pantanal (Рicoloto et al., 2010). Since 1985, researchers have warned about the importance of studying the pampas deer as a reservoir for cattle diseases (MACHADO et al. 1985; SERRA-FreIre et al., 1996; Ito et al., 1998). 
Tab. I. Domestic hosts: Prevalence (\%) and number of ticks collected per host species in southern Pantanal (N, number of hosts examined; 1 , Amblyomma larvae; nn, Amblyomma nymphs).

\begin{tabular}{|c|c|c|c|c|c|c|c|c|}
\hline \multirow{2}{*}{ Hosp./N } & \multicolumn{8}{|c|}{ Prevalence/number of ticks } \\
\hline & 1 & $\mathrm{n}$ & A. cajennense & A. parvum & A. ovale & D. nitens & R. (B.) microplus & O. rostratus \\
\hline bovine/174 & 0 & 0 & $2 \% / 4$ & $1 \% / 2$ & 0 & 0 & $36 \% / 96$ & 0 \\
\hline horses/21 & 0 & 0 & $43 \% / 18$ & 0 & 0 & $57 \% / 51$ & 0 & 0 \\
\hline pigs/06 & 0 & 0 & $100 \% / 24$ & 0 & 0 & 0 & 0 & 0 \\
\hline $\operatorname{dogs} / 24$ & $12 \% / 79$ & $38 \% / 42$ & $25 \% / 7$ & $21 \% / 18$ & $17 \% / 4$ & 0 & 0 & $21 \% / 6$ \\
\hline
\end{tabular}

Tab. II. List of the Amblyomma ticks and the hosts' relationships found in the Pantanal, Mato Grosso do Sul, Brazil. [A, collected data; B, based on the major Brazilian scientific collections (ONÓFrio, 2007); C, bibliography (MACHADO et al., 1985; Ito et al., 1998; Pereira et al., 2000; MARTINS et al., 2004, Labruna et al., 2005); *, new parasitic relationship to the Pantanal area].

\begin{tabular}{|c|c|c|c|}
\hline Tick species & Host species & Host common names & Records \\
\hline A. sculptum & $\begin{array}{l}\text { Canis familiaris } \\
\text { Cerdocyon thous } \\
\text { Procyon cancryvorus } \\
\text { Panthera onca } \\
\text { Puma concolor } \\
\text { Leopardus pardalis } \\
\text { Nasua nasua } \\
\text { Masama guazoubira } \\
\text { Ozotoceros bezoarcticus* } \\
\text { Blastoceros dichotomus } \\
\text { Hydrochoeris hydrochoeris } \\
\text { Dasiprocta azarae } \\
\text { Trichomys sp.* } \\
\text { Equus caballus } \\
\text { Tapirus terrestris } \\
\text { Bos taurus/B. indicus } \\
\text { Sus scrofa } \\
\text { Tayassu pecari } \\
\text { Tayassu tajacu* } \\
\text { Mymerpophaga tridactyla } \\
\text { Tamandua tetradactyla } \\
\text { Dasypodidae } \\
\text { Coendou prehensilis } \\
\text { Homo sapiens sapiens }\end{array}$ & $\begin{array}{l}\text { domestic dog } \\
\text { crab-eating fox } \\
\text { crab-eating raccon } \\
\text { puma } \\
\text { jaguar } \\
\text { oncelot } \\
\text { brown-nose coati } \\
\text { catingueiro deer } \\
\text { pampas deer* } \\
\text { marsh deer } \\
\text { capybara } \\
\text { agouti } \\
\text { small rodent* } \\
\text { horse } \\
\text { tapir } \\
\text { bovine } \\
\text { feral/domestic pig } \\
\text { queixada pig } \\
\text { caititu pig* } \\
\text { giant ant-eater } \\
\text { collared ant-eater } \\
\text { armadillo } \\
\text { hedgehog } \\
\text { humans }\end{array}$ & $\mathrm{A}, \mathrm{B}, \mathrm{C}$ \\
\hline A. calcaratum & $\begin{array}{l}\text { M. tridactyla } \\
\text { T. tetradactyla }\end{array}$ & $\begin{array}{l}\text { giant ant-eater } \\
\text { collared ant-eater }\end{array}$ & $\mathrm{B}$ \\
\hline & $\begin{array}{l}\text { P. onca } \\
\text { P. concolor }\end{array}$ & $\begin{array}{l}\text { puma } \\
\text { jaguar }\end{array}$ & \\
\hline A. coelebs & $\begin{array}{l}\text { T. terrestris } \\
\text { T. pecari } \\
\text { T. tajacu } \\
\text { Chelonoidis carbonaria* }\end{array}$ & $\begin{array}{l}\text { tapir } \\
\text { queixada pig } \\
\text { caititu pig } \\
\text { tortoise* }\end{array}$ & $\mathrm{B}, \mathrm{C}$ \\
\hline A. dissimilie & $\begin{array}{l}\text { Bothrops matogrossensis } \\
\text { Amphibia } \\
\text { C. thous }\end{array}$ & $\begin{array}{l}\text { jararaca snake } \\
\text { amphíbians } \\
\text { crab-eating fox }\end{array}$ & $\mathrm{A}, \mathrm{B}$ \\
\hline A. dubitatum & $\begin{array}{l}\text { M. guazoubira } \\
\text { H. hydrochoeris } \\
\text { T. terrestris }\end{array}$ & $\begin{array}{l}\text { catingueiro deer } \\
\text { capybara } \\
\text { tapir }\end{array}$ & $\mathrm{B}$ \\
\hline A. scalpturatum & $\begin{array}{l}\text { M. tridactyla } \\
\text { C. familiaris } \\
\text { S. scrofa }\end{array}$ & $\begin{array}{l}\text { giant ant-eater } \\
\text { domestic dog } \\
\text { feral/domestic pig }\end{array}$ & $\mathrm{C}$ \\
\hline A. naponense & $\begin{array}{l}\text { T. pecari } \\
\text { T. tajacu } \\
\text { H. sapiens sapiens }\end{array}$ & $\begin{array}{l}\text { queixada pig } \\
\text { caititu pig } \\
\text { humans }\end{array}$ & B \\
\hline A. nodosum & $\begin{array}{l}\text { M. tridactyla } \\
\text { T. tetradactyla }\end{array}$ & $\begin{array}{l}\text { giant ant-eater } \\
\text { collared ant-eater }\end{array}$ & $\mathrm{B}, \mathrm{C}$ \\
\hline A. ovale & $\begin{array}{l}\text { C. familiaris } \\
\text { Felis catus } \\
\text { C. thous } \\
\text { P. cancryvorus } \\
\text { P. onca } \\
\text { P. concolor } \\
\text { L. pardalis }\end{array}$ & $\begin{array}{l}\text { domestic dog } \\
\text { domestic cat } \\
\text { crab-eating fox } \\
\text { crab-eating raccon } \\
\text { puma } \\
\text { jaguar } \\
\text { oncelot }\end{array}$ & $\mathrm{A}, \mathrm{B}, \mathrm{C}$ \\
\hline
\end{tabular}


Tab. II. Cont.

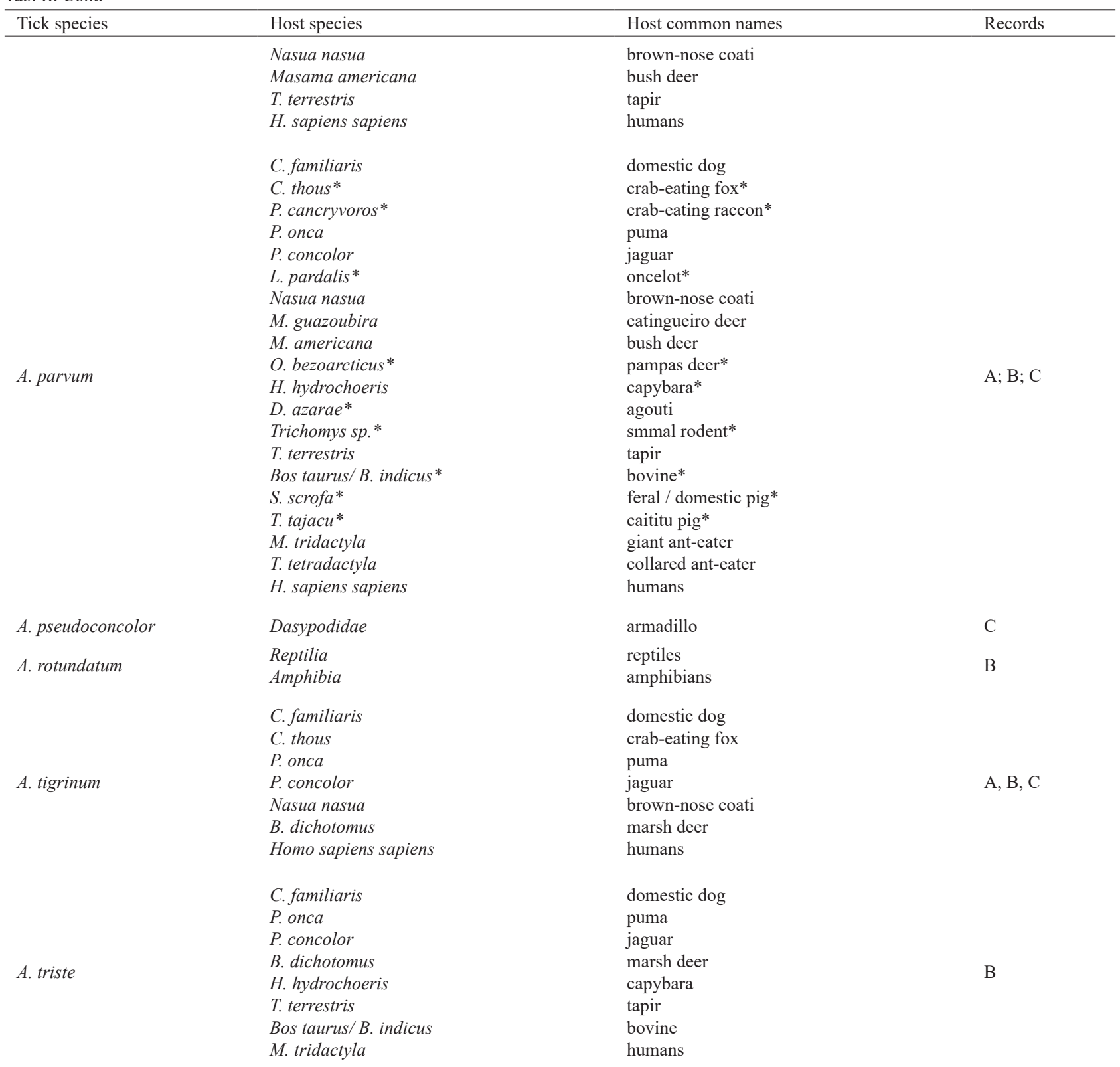

Tab. III. Wild hosts: Prevalence (\%) and number of ticks collected per host species in southern Pantanal (N, number of hosts examined; 11, Amblyomma larvae; nn, Amblyomma nymphs).

\begin{tabular}{lcccccc}
\hline \multirow{2}{*}{ Hosp. } & $\mathrm{N}$ & \multicolumn{5}{c}{ Prevalence/number of ticks } \\
\cline { 3 - 6 } & & 11 & $\mathrm{nn}$ & A. sculptum & A. parvum & A. ovale \\
\hline C. thous & 42 & $21 \% / 50$ & $60 \% / 271$ & $17 \% / 13$ & $50 \% / 65$ & $14 \% / 10$ \\
N. nasua & 37 & $27 \% / 123$ & $76 \% / 211$ & $11 \% / 6$ & $48 \% / 52$ & $48 \% / 46$ \\
P.cancryvorus & 2 & $50 \% / 1$ & $50 \% / 11$ & $50 \% / 3$ & $100 \% / 27$ & $100 \% / 15$ \\
L. pardalis & 18 & $50 \% / 234$ & $3 \% / 1$ & $3 \% / 8$ & $88 \% / 98$ & $3 \% / 1$ \\
S. scrofa & 42 & 0 & $2 \% / 1$ & $100 \% / 259$ & $14 \% / 8$ & 0 \\
T. tajacu & 3 & 0 & $100 \% / 20$ & $100 \% / 13$ & $100 \% / 11$ & 0 \\
D. azarae & 4 & 0 & $100 \% / 13$ & $25 \% / 3$ & $50 \% / 3$ & 0 \\
Thrychomys & 37 & $100 \% / 123$ & $94 \% / 188$ & 0 & $8 \% / 3$ & $3 \% / 1$ \\
M. tridactyla & 17 & $40 \% / 58$ & $100 \% / 332$ & $94 \% / 138$ & $47 \% / 17$ & $6 \% / 1$ \\
T. tetradactyla & 3 & $33 \% / 1$ & $33 \% / 3$ & $66 \% / 7$ & $100 \% / 5$ & 0 \\
\hline
\end{tabular}


Amblyomma tigrinum Koch, 1844. Only one $A$. tigrinum male was found on 42 foxes, 37 coatis and 24 dogs surveyed, indicating low prevalence of this tick in the studied region. This tick species was found elsewhere on coati $(N$. nasua), puma (Puma concolor) and jaguar (Panthera onca) (PEREIRA et al., 2000; ONÓFrio, 2007).

Amblyomma dissimile Koch, 1844. This tick is specialized in feeding on cold-blooded animals primarily reptiles (BARRos-BATTESTI et al., 2006). Four tortoises (Chelonoidis carbonaria Spix, 1824) and seven snakes ("jararaca" - Bothrops matogrossensis) were examined. Adult ticks (A. dissimile) were found on two tortoises and three snakes.

A total of 16 adults were collected on snakes and one of them was parasitized by five Amblyomma spp. larvae. On the tortoise, ticks were found on its legs, near the body and protected by the carapace. This species was also found feeding on amphibians in the Pantanal and was reported to feed on humans (ONÓFrio, 2007).

Amblyomma parvum Aragão, 1908. One of the most abundant and widely distributed species in the Nhecolandia region of the Pantanal is A. parvum. This tick has low specificity during all stages of the life-cycle, including the adult stage. It was collected from almost all examined host species including all wild and domestic carnivores (P. cancrivorus, N. nasua, L. pardalis, C. thous and C. familiaris), small (Thrichomys spp., Clyomys sp., D. asarae) and big rodent (Hydrochoeris hydrochoeris), bovines, feral and domestic pigs, collared peccary (Tayassu tajacu), giant ant-eater ( $M$. tridactyla) and collared ant-eater (T. tetradactyla). This tick species has also been reported on puma and jaguar ( $P$. concolor and $P$. onca), different species of deer (Masama americana and M. guazoubira) and tapir (Tapirus terrestris) (Tabs I-III). Amblyomma parvum nymphs were found feeding on all examined host species. It is worth noting the high number of engorged nymphs found on small rodents which molted to adults. A total of $87 \%(n=201)$ of nymphs from small rodents (Thrichomys spp.; D. asarae) molt to A. parvum adults. In Argentina, the rodent Galea musteloides (Caviidae) is classified as the major host for immature $A$. parvum (NAVA et al., 2006).

Moreover, A. parvum was frequently found feeding on humans, which had also been previously described by other authors from Argentina and Brazil (GUGLIELMONE et al., 2006, SzABó et al., 2007). Different from A. sculptum, the $A$. parvum bites do not hurt, allowing this tick to attach and feed for long periods without being noticed. Thus, it amplifies the risk of transmission of some tick-borne diseases, such as rickettsiosis. The first identification of a Rickettsia sp. from A. parvum was performed by PACHECO et al. (2007). It is interesting to note that two engorged nymphs, collected on humans molted to adults.

Amblyomma parvum has a wide geographic distribution, occurring in several Brazilian states and in different environments such as rainforest and savanna (Mullins et al., 2004; SzABó et al., 2007), as well as environments with milder weather such as northern Argentina.
Amblyomma ovale Koch, 1844. This species was frequently found in the Pantanal. A total of 83 adult ticks were collected of which 42 were males and 41 females from 123 animals: two raccoons ( $P$. cancrivorus) 18 ocelots $(L$. pardalis), 24 dogs (C. familiaris), 37 coatis ( $N$. nasua) and 42 foxes (C. thous). Nymphs collected on small rodents (Thrichomys spp.) after ecdysis were identified as $A$. ovale (Tab. III). The scientific literature also includes the puma (P. concolor), jaguar (P. onca), ocelot (L. pardalis) and the domestic cat (F. catus) in the list of hosts for A. ovale in the Pantanal (Tab. II). These data strongly suggest that carnivores are the primary hosts for adult ticks. Specimens have been found on deer ( $M$. americana) and tapir ( $T$. terrestris) (ONOFRIO, 2007), although these findings appear to be accidental.

Some bioagents are associated with $A$. ovale. FORLANO et al. (2005) included this species as a potential vector of Hepatozoon canis, from experimental studies. There are no studies of this agent in the Pantanal, however it should be noted that there are some findings of $H$. canis and $H$. procyonis in wild carnivores ( $P$. cancrivoros and $N$. nasua) in other regions of Brazil (MASSARD \& MASSARD, 1978; SCHNEIDER, 1968; RODRIGUES, 2005). LABRUNA et al., (2004) found an infection rate of $28 \%$ Rickettsia bellii in $A$. ovale in the Amazon region, although $R$. bellii is regarded as nonpathogenic. Finally, the constant introduction of dogs from urban centers in the Pantanal region might favor the introduction of biological agents endangering native fauna.

Amblyomma cajennense (Fabricius, 1787). After the reassessment of the taxonomic status and distribution of A. cajennense in Brazil (NAVA et al. 2014; EstradA-PEÑA et al., 2014; MARTINs et al., 2016) we assume that all records from Brazilian Pantanal are A. sculptum. Moreover, we review our field samples and all ticks are $A$. sculptum. The distribution of $A$. sculptum in Brazil generally encompass the entire Cerrado and Pantanal biomes and great part of the Atlantic forest biome (MARTINs et al., 2016).

The importance of this tick is due to its wide geographic distribution, low host specificity and proven role in the epidemiology of the Brazilian Spotted Fever. In the studied area, it was the most abundant species within samples collected in the environment (CANÇADO et al., 2008) and also on all hosts examined (Tab. II), particularly on the carnivores studied (Tab. III). In addition, species such as the giant-ant-eater and feral pigs are extremely parasitized by this species with $100 \%$ prevalence and high infestation intensity (more than 30 tick per animal).

The great importance of this species is due to its low specificity, high abundance and wide geographic distribution (BARRos-BATTESTI et al., 2006). Furthermore, its role as an experimental vector of Ehrlichia ruminantium (Cowdria ruminantum) in the Antilles highlights the importance of monitoring this agent in the Pantanal, a reproductive hotspot for dozens of migrating birds that may aid in tick dissemination.

The fact that $A$. sculptum has been found parasitizing a wide variety of native wildlife species make their control 
very difficult with the currently available technologies. Environmental control by acaricides would be catastrophic because of the impact on the regional biodiversity and contamination of water samples. There are no studies about the importance of $A$. cajennense in livestock production in the Pantanal.

Amblyomma calcaratum Neumann, 1899. The adult stage seems to be associated exclusively with anteaters, however, immature stages are frequently found on birds. It has wide geographic distribution occurring from Argentina to Panama. (Barros-Battesti et al., 2006). Although $A$. calcaratum has been identified in the Pantanal (ONÓFrIO, 2007) parasitizing two species of anteaters (M. tridactyla and T. Tetradactyla). MARTINs et al. (2004) did not find this species on this host. In the present study, we sampled ticks from 17 giant- and 3 collared-anteaters and no $A$. calcaratum were found. It is likely that this species is rare in the region or is restricted to limited environments, such as gallery forests, which were not sampled. However, the great similarity of $A$. calcaratum and $A$. nodosum should be considered and may contribute to misdiagnosis.

Amblyomma coelebs Neumann, 1899. This species has been recorded in the Pantanal on peccary pig and queixada pig (Tayassu pecari and T. tajacu) and tapir (Tapirus terrestris) (ONóFrIo, 2007) and also on puma and jaguar (P. onca and P. concolor) (LABRUNA et al., 2005a; ONóFrio, 2007). Although A. coelebs was not found in this survey, it is possible that it is present since tapirs are common and these were not examined.

Amblyomma dubitatum Neumann, 1899. This species is mainly associated with capybaras (H. hydrochoeris). However, occasionally it can be found on different hosts (Barros-Battesti et al., 2006; ONófrio, 2007). This tick is important to the Brazilian Spotted Fever epidemiology because in many cases the occurrence of this disease is related to the presence of $A$. dubitatum and capybaras and this host is abundant in the Pantanal. The replacement of traditional cattle for grain crops such as soybeans, can favor the multiplication of capybaras that could become a pest. Iто et al. (1998) examined capybaras in the same region and the only tick species found was $A$. sculptum.

Amblyomma scalpturatum Newmann, 1906. There is only one record of this species in the Pantanal. It was found parasitizing a giant-anteater (M. tridactyla) (PEREIRA et al., 2000), however, this tick species was not found in the present study. Thus, it is likely that this species is rare in the region or was an accidental finding.

Amblyomma naponense (Packard, 1869). The findings of this tick species in the Brazilian Pantanal are related to the order Artiodactyla: S. scrofa, T. peccary and T. tajacu (ONóFrio, 2007). Despite the large number of sampled animals in this group (40), the species A. naponense was not found in the study region. Thus, it is likely to be restricted to other lowland regions.

Amblyomma nodosum Neumann, 1899. The adults of this species are frequently found parasitizing the collared anteater or giant anteater (MARTINs et al., 2004). In the present study, this tick was not found. However, only three collared anteaters were examined.

Amblyomma pseudoconcolor Aragão, 1908. This species was found parasitizing an armadillo (E. sexcintus) in the Nhecolândia sub-region (PereIRA et al., 2000). Very little is known about $A$. pseudoconcolor. However, it appears that the immature stages can parasitize birds (ARAGÃO, 1936). In the present study, all the ticks collected on armadillos were $A$. cajennense.

Amblyomma rotundatum Koch, 1844 . There are records of this species parasitizing reptiles and amphibians in the region. Its main feature is that biological females reproduce by parthenogenesis and the males are very rare (LABRUNA et al., 2005b). According to regional farm workers, it is common to see a "large tick" on cururu toads, although amphibians (Bufonidae) have been examined (25) no tick was found.

Amblyomma triste Koch, 1844. This tick species has been found on different hosts. ONóFrIo (2007) listed records of scientific collections, which included: puma, jaguar, cattle, the marsh deer, tapir, capybara, and domestic dog as hosts. The main host of $A$. triste is most probably the marsh deer (B. dichotomus) (SzABó et al., 2003), however, it was not examined during the study.

Acknowledgements. To Fundação de Apoio ao Desenvolvimento do Ensino, Ciências e Tecnologia do Estado de Mato Grosso do Sul (Fundect) and Superintendência de Ciências e Tecnologia do Estado de Mato Grosso do Sul (Sucitec/MS) for the invitation to participate in this special issue of Iheringia, Série Zoologia and financial support for publication. We thank Dr. Manuel Venzal for your help in confirming the identification of ticks Orniothodorus.

\section{REFERENCES}

Aragão, H. B. 1936. Ixodidas brasileiros e de alguns países limitrophes. Memórias do Instituto Oswaldo Cruz 31:759-844.

Barros-Battesti, D. M.; Arzua, M. \& Bechara, G. H. 2006. Carrapatos de importância médico-veterinária da região neotropical: um guia ilustrado para identificação de espécies. São Paulo, Vox, ICTTD-3, Butantan. 223p.

Borges, L. M. F. \& Leite, R. C. 1993. Comparação entre as populações auriculares e nasais de Dermacentor nitens (Neumann, 1897) oriundas de eqüinos de Minas Gerais e Bahia, Brasil. Revista Brasileira de Parasitologia Veterinária 2:109-110.

Cançado, P. H. D.; Piranda, E. M.; Faccini, J. L. H. \& Mourão, G. M. 2008. Spatial distribution and impact of cattle-raising on ticks in the Pantanal region of Brazil by using the $\mathrm{CO}(2)$ tick trap. Parasitology Research 103:1-7.

Cançado, P. H. D.; Zucco, C. A.; Piranda, E. M.; Mourão, G. M. \& FACCINI, J. L. H. 2009. Rhipicephalus (Boophilus) microplus (Acari: Ixodidae) as a parasite of pampas-deer (Ozoctoceros bezoarticus) and cattle in Central Pantanal of Brazil. Revista Brasileira de Parasitologia Veterinária 18:42-46.

Estrada-Peña, A.; Tarragona, E. L.; Vesco, U.; Meneghi, D.; Mastropaolo, M.; Mangold, A. J.; Guglielmone, A. A. \& Nava, S. 2014. Divergent environmental preferences and areas of sympatry of tick species in the Amblyomma cajennense complex (Ixodidae). International Jornal for Parasitology 44:1081-1089.

Forlano, M.; Scofield, A.; Elisei, C.; Fernandes, K. R.; Ewing, S. A. \& MASSARD, C. L. 2005. Diagnosis of Hepatozoon spp. in Amblyomma ovale and its experimental transmission in domestic dogs in Brazil. Veterinary Parasitology 134:1-7. 
Guglielmone, A. A.; Beati, L.; Barros-Battesti, D. M.;Labruna, M. B.; NaVA, S.; Venzal, J. M.; Mangold, A. J.; SzabÓ, M. P. J.; Martins, J. R.; GonZÁlez-Acuña, D. \& Estrada-Peña, A. 2006. Ticks (Ixodidae) on humans in South America. Experimental and Applied Acarology 40:83-100.

Guglielmone, A. A. \& Hadani, H. 1980. Ciclo biológico de Ornithodoros rostratus Aragão, 1911, bajo condiciones de laboratorio. Revista Medicina Veterinaria (Buenos Aires) 61:254-257.

Guimarães, J. H.; Tucci, E. C. \& Barros-Battesti, D. M. 2001. Ectoparasitos de Importância Veterinária. São Paulo, Editora Plêiade/ FAPESP. 218p.

Hoogstraal, H. 1985. Argasid and Nutalliellid ticks as parasites and vectors. Advances in Parasitology 24:135-238.

Ito, F. H.; Vasconcellos, S. A.; Bernardi, F.; Nascimento, A. A.; Labruna, M. B. \& Arantes, I. G. 1998. Evidência sorológica de Brucelose e leptospirose e parasitismo por Ixodídeos em animais silvestres do Pantanal Sul-Mato-Grossense. Ars Veterinaria 14:302-310.

LabrunA, M. B. 2009. Ecology of Rickettsia in South America. Annals of the New York Academy of Sciences 1166:156-166.

Labruna, M. B.; Jorge, R. S. P.; Sana, D. A.; Jacomo, A. T. A.; Kashivakura, C. K.; Furtado, M. M.; Ferro, C.; Perez, S. A.; Silveira, L.; Santos, T. S.; Marques, S. R.; Morato, R. G.; Nava, A.; Adania, C. H.; Teixeira, R. H. F.; Gomes, A. A. B.; Conforti, V. A.; Azevedo, F. C. C.; Prada, C. S.; Silva, J. C. R.; Batista, A. F.; Marvulo, M. F. V.; Morato, R. L. G.; Alho, C. J. R.; Pinter, A.; Ferreira, P. M.; Ferreira, F. \& Battesti, D. M. B. 2005a. Ticks (Acari: Ixodida) on wild carnivores in Brazil. Experimental and Applied Acarology 36:149-163.

Labruna, M. B.; Terrassini, F. A. \& Camargo, L. M. A. 2005b. First report of the male of Amblyomma rotundatum (Acari: Ixodidae) from a field-collected host. Journal of Medical Entomology 42(6):945-947.

Labruna, M. B.; Whitworth, T.; Bouyer, D.; McBride, J.; Camargo, L. M. A. C.; Camargo, E.; Popov, W. \& Walker, D. 2004. Rickettsia bellii and Rickettsia amblyommii in Amblyomma Ticks from the State of Rondônia, Western Amazon, Brazil. Journal of Medical Entomology 41(6):1073-1081.

Lemos-Monteiro, J.; Fonseca, F. \& Prado, A. 1932. Typho endêmico de São Paulo - VI. Pesquisas sobre a possibilidade da transmissão experimental do vírus por Ixodidae. Brasil Médico 46(3):49-52.

Machado, R. Z.; Machado, C. R.; Toledo, C. Z. P.; Ferreira, F. A. \& RochA, U. F. 1985. Ecologia em carrapatos XIII - Boophilus microplus (Canestrini, 1887) em infestações naturais de veados (Ozotocerus bezoarticus bezoarticus Linnaeus, 1766) e capivaras (Hydrochoerus hydrochoris hydrochoeris Linnaeus, 1762) dos estados de São Paulo e Mato Grosso do Sul. Ars Veterinária 1(1):47-50.

Martins, J. R.; Medri, I. M.; Oliveira, C. M. \& Guglielmone, A. 2004. Ocorrência de carrapatos em tamanduá-bandeira (Myrmecophaga tridactyla) e tamanduá-mirim (Tamandua tetradactyla) na região do Pantanal Sul-Mato-Grossense, Brasil. Ciência Rural 34(1):293-295.

Martins, T. F.; Barbieri, A. R. M.; Costa, F. B.; Terassini, F. A.; Camargo, L. M. A.; Peterka, C. L. R.; Pacheco, R. C.; Dias, R. A.; Nunes, P. H.; Marcili, A.; Scofield, A.; Campos, A.; Horta, M.; GuillouX, A. G. A.; Benatti, H. R.; Ramirez, D. G.; Barros-Battesti, D. M. \& LabrunA, M. B. 2016. Geographical distribution of Amblyomma cajennense (sensu lato) ticks (Parasitiformes: Ixodidae) in Brazil, with description of the nymph of $A$. cajennense (senso strictu). Parasites \& Vectors 9(186): 1-14

Massard, C.A. \& MASSARD, C. L. 1978. Hepatozoon procyonis Richards, 1961 (Protozoa: Haemogregarinidae) em Procyon cancrivorus (Goldman) no estado do Rio de Janeiro. In: Anais do Congresso da Sociedade Brasileira de Medicina Tropical e III Congresso da Sociedade Brasileira de Parasitologia. João Pessoa, PB, Sociedade Brasileira de Parasitologia, p.401.

McCallum, H. \& Dobson, A. 2002. Disease, habitat fragmentation and conservation. Proceedings of the Royal Society B, Biological Sciences 269:2041-2049.
Mullins, M. C.; Lazzarini, S. M. \& Picanço, M. C. L. 2004. Amblyomma parvum a parasite of Dasypus kappleri in the state of Amazonas, Brazil. Journal of Agricultural Science 42:287-291.

Nava, S.; Mangold, A. J. \& Guglielmone, A. A. 2006. The natural hosts for larvae and nymphs of Amblyomma neumanni and Amblyomma parvum (Acari: Ixodidae). Experimental and Applied Acarology 40:123-131.

ONÓFrio V. C. 2007. Revisão do gênero Amblyomma Koch, 1884 (Acari: Ixodidae) no Brasil. Tese de Doutorado. Universidade Federal Rural do Rio de Janeiro, Seropédica, Rio de Janeiro.

Pacheco, R. C.; Moraes-Filho, J.; Nava, S.; Brandão, P. E.; Richtzenhain, L. J. \& LABRUNA, M. B. 2007. Detection of a novel spotted fever group rickettsia in Amblyomma parvum ticks (Acari: Ixodidae) from Argentina. Experimental and Applied Acarology 43:63-71.

Pereira, M. C.; Szabó, M. P. J.; Bechara, G. H.; Matushima, E. K.; Duarte, J. M. B.; RechaV, Y.; Fielden, L. \& Keirans, J. 2000. Ticks (Acari:Ixodidae) associated with wild animals in the Pantanal Region of Brazil. Journal of Medical Entomology 37:979-983.

Picoloto, G.; Lima, R. F.; Olegário, L. A. O.; Carvalho , C. M. E.; Lacerda, A. C. R.; Tomás, W. M.; Borges, P. A. L.; Pellegrin, A. O. \& MAdrugA, C. R. 2010. Real time polymerase chain reaction to diagnose Anaplasma marginale in cattle and deer (Ozotoceros bezoarticus leucogaster) of the Brazilian Pantanal. Revista Brasileira de Parasitologia Veterinária 19(3):186-188.

Piovezan, U.; Zucco, C. A. \& Rocha, F. L. 2006. First report of darting to capture the pampas deer (Ozotoceros bezoarticus). Deer Specialist Group News 21:3-7.

Rocha, F. L. 2006. Áreas de uso e seleção de habitats de três espécies de carnívoros de médio porte na Fazenda Nhumirim e arredores, Pantanal da Nhecolândia, MS. Dissertação de Mestrado. Universidade Federal de Mato Grosso do Sul, Campo Grande, Mato Grosso de Sul.

Rodela, L. G.; Santos, S. A.; Pellegrin, L. A.; Ravaglia, A.; Mazin, V. \& QueIROZ-Neto, J. P. DE. 2008. Mapeamento de unidades de paisagem em nível de fazenda, Pantanal de Nhecolêndia. Boletim de Pesquisa e Desenvolvimento 83:1-24.

Rodrigues, A. F. S. F. 2005. Contribuição ao conhecimento hemoparasitológico e ectoparasitológico em Procinídeos brasileiros. Tese de Doutorado. Universidade Federal Rural do Rio de Janeiro, Seropédica, Rio de Janeiro.

Santos, H. A.; Angelo, I. C.; Franque, M. P.; Vashist, U.; Duarte, A. F.; Baldani, C. D.; Thome, S. M. G.; Faccini, J. L. H. \& Massard, C. L. 2010. The influence of the fasting period on the number of nymphal instars and on the sex ratio of Argas (Persicargas) miniatus (Acari: Argasidae). Revista Brasileira de Parasitologia Veteterinária 19:164-168.

SCHNeIDER, C. R. 1968. Hepatozoon procyonis Richards 1961, in a Panamanian raccoon, Procyon cancrivorus panamensis (Goldman). Revista de Biologia Tropical 15(1):123-135.

Serra-Freire, N. M.; Amorim, M.; Gazeta, G. S.; Guerim, L. \& Desidério, M. H. G. 1996. Ixodofauna de cervídeos no Brasil. Revista Brasileira de Ciência Veterinária 3(2):51-54.

Soriano, B. M. A.; Oliveira, H.; Catto, J. B.; Filho, J. A. C.; Galdino, S. \& SAlis, S. M. 1997. Plano de utilização da Fazenda Nhumirim. Corumbá, Embrapa Pantanal. (Documentos, 21).

Szabó, M. P. J.; Castro, M. B.; Ramos, H. G. C.; Garcia, M. V.; Castagnolli, K. C.; Pinter, A.; Veronez, V. A.; Magalhães, G. M.; Duarte, J. M. B. \& Labruna, M. B. 2007. Species diversity and seasonality of free-living ticks (Acari: Ixodidae) in the natural habitat of wild Marsh deer (Blastocerus dichotomus) in southeastern Brazil. Veterinary Parasitology143:147-154.

Szabó, M. P. J.; Labruna, M. B.; Pereira, M. C. \& Duarte, J. M. B. 2003. Ticks (Acari: Ixodidae) on Wild Marsh-Deer (Blastocerus dichotomus) from Southeast Brazil: Infestations before and after habitat loss. Journal of Medical Entomology 40(3):268-274.

Tomas, W. M. 1995. Seasonality of the antler cycle of pampas deer (Ozotoceros bezoarticus leucogaster) from the Pantanal Wetland, Brazil. Studies on Neotropical Fauna and Environment 30(4):221-227. 